\title{
ANALISIS KEMAMPUAN GURU SEKOLAH DASAR DALAM MENGEMBANGKAN KETERAMPILAN SOSIAL SISWA PADA PEMBELAJARAN IPS
}

\author{
Suharli $^{1)}$, Muhammad Iksan ${ }^{2)}$, Jhon Kenedi ${ }^{3)}$ \\ Fakultas Keguruan dan Ilmu Pendidikan, Universitas Samawa (Suharli) \\ suharliyazupal@yahoo.com \\ Fakultas Keguruan dan Ilmu Pendidikan, Universitas Samawa (Muhammad Iksan) \\ Iksan_unsa@yahoo.co.id \\ Fakultas Keguruan dan Ilmu Pendidikan, Universitas Samawa (Jhon Kenedi) \\ jhonkenedi92@yahoo.com
}

\begin{abstract}
Abstrack
All education paradigm in Indonesia developed to form the character and prestigious nation civilization in order to educating nation life, aim to develop the competitor potency educated in order to become the godly and religious human being to God, august behavior, healthy, bookish, capable, creative, self-supporting, and become the democratic citizen and also hold responsible. This Research target is to know the teacher ability in developing student interest to social studies education like: improving social skill of student. This research design is using descriptive method qualitative. With implementation of this research is detectable hence effort which must be done by teacher to increase social skill of student so that expected to affect its behavior in society.

Pursuant to data analyses, the inferential research data that $62.5 \%$ teacher of social studies in Elementary School at Sumbawa not yet able to maximally in developing interest social skill of student that seen from dominant method used, relevant method by scenario at student activity in teaching learning, and also result of observation during teaching learning process. However pursuant to formula of instruction target $62.5 \%$ teacher formulated the interest of cognitif domain, afectif, and psicomotor is inclusive social skill of student.
\end{abstract}

\begin{abstract}
Abstrak
Seluruh paradigma pendidikan di Indonesia dikembangkan untuk membentuk watak dan peradaban bangsa yang bermartabat dalam rangka mencerdaskan kehidupan bangsa, bertujuan untuk mengembangkan potensi peserta didik agar menjadi manusia yang beriman dan bertakwa kepada Tuhan Yang Maha Esa, berakhlak mulia, sehat, berilmu, cakap, kreatif, mandiri, dan menjadi warga negara yang demokratis serta bertanggung jawab. Tujuan penelitian ini adalah untuk mengetahui kemampuan guru dalam mengembangkan kompetensi siswa pada pembelajaran IPS seperti: meningkatkan kompetensi keterampilan sosial peserta didik. Penelitian ini dirangcang dengan menggunakan metode deskriptif kualitatif. Dengan dilaksanakannya penelitian ini maka dapat ditemukan upaya yang harus dilakukan oleh guru melalui pembelajaran untuk meningkatkan keterampilan sosial siswa sehingga diharapkan berdampak pada perilakunya di dalam masyarakat.

Berdasarkan deskripsi dan analisis data penelitian dapat disimpulkan bahwa $62.5 \%$ guru IPS Sekolah Dasar di kecamatan Sumbawa belum mampu secara maksimal dalam mengembangkan kompetensi keterampilan social siswa baik dilihat dari metode yang dominan digunakan, relevansi metode dengan sekenario pada kegiatan inti pembelajaran, maupun hasil observasi selama proses pembelajaran berlangsung. Akan tetapi berdasarkan rumusan tujuan pembelajaran $62.5 \%$ guru sudah merumuskan kompetensi pada ranah kognitif, afektif, dan psikomotor termasuk keterampilan sosial siswa di dalamnya.
\end{abstract}

Kata Kunci: Kemampuan Guru, Keterampilan Sosial 


\section{Pendahuluan}

Seluruh paradigma pendidikan di Indonesia dikembangkan untuk membentuk watak dan peradaban bangsa yang bermartabat dalam rangka mencerdaskan kehidupan bangsa, bertujuan untuk mengembangkan potensi peserta didik agar menjadi manusia yang beriman dan bertakwa kepada Tuhan Yang Maha Esa, berakhlak mulia, sehat, berilmu, cakap, kreatif, mandiri, dan menjadi warga negara yang demokratis serta bertanggung jawab. Dalam tujuan pendidikan tersebut sangat sarat dengan kompetensi sosial, personal, dan akademis. Karena itu kurikulum pun dikembangkan berdasarkan prinsip-prinsip (1) berpusat pada potensi, perkembangan, kebutuhan dan kepentingan peserta didik dan lingkungannya, (2) beragam dan terpadu (3) tanggap terhadap perkembangan ilmu pengetahuan, teknologi, dan seni, (4) relevan dengan kebutuhan kehidupan, (5) menyeluruh dan berkesinambungan, (6) belajar sepanjang hayat (7) seimbang antara kepentingan nasional dan kepentingan daerah.

Sejalan dengan kondisi tersebut di atas, berdasarkan hasil pengamatan proses pembelajaran IPS di sekolah dasar ditemukan bahwa sebagian besar guru lebih memperhatikan penguasaan konsep yang ditunjukkan berupa hasil belajar secara kognitif dari pada proses dan keterampilan yang diperoleh siswa selama proses pembelajaran. Disamping itu, proses pembelajaran masih berpusat pada guru sehingga berdampak pada lemahnya keterampilan siswa yang dapat dibentuk oleh guru melalui proses pembelajaran IPS di sekolah dasar. Dengan demikian maka tidak menutup kemungkinan setelah mengalami proses pembelajaran IPS, kompetensi siswa terutama yang terkait dengan kompetensi pada ranah apektif dan psikomotor sama sekali tidak tersentuh.

\section{Kajian Literatur dan Pengembangan Hipotesis}

Adapun rumusan masalah yang diajukan dalam penelitian ini adalah bagaimanakah kemampuan guru dalam mengembangkan keterampilan sosial siswa pada mata pelajaran IPS di sekolah dasar yang dirincikan sebagai berikut: (a) Bagaimanakah kemampuan guru dalam mengembangkan keterampilan sosial siswa berdasarkan analisis jenis metode yang dominan digunakan dalam pembelajaran IPS, (b) Bagaimanakah kemampuan guru dalam mengembangkan keterampilan sosial siswa berdasarkan analisis rumusan RPP yang telah dibuat, (c) Bagaimanakah kemampuan guru dalam mengembangkan keterampilan sosial siswa berdasarkan analisis tingkat keterlibatan siswa untuk melakukan kerjasama dalam pembelajaran.

\section{Metode Penelitian}

Penelitian ini dirangcang dengan menggunakan metode penelitian deskriptif kualitatif. Dalam rancangan ini, peneliti mendeskripsikan fenomena objek penelitian, mengumpulkan dan menceritakan informasi tentang fenomena objek penelitian tersebut, serta melaporkannya secara naratif tentang informasi-informasi yang telah ditemukan. Dengan demikian maka dalam penelitian ini peneliti mendeskripsikan tentang kemampuan guru dalam mengembangkan keterampilan sosial siswa pada pembelajaran IPS dengan indikator munculnya perilaku saling 
menghargai, kerjasama dan tolong menolong. Indikator tersebut dapat dikembangkan oleh guru dengan menerapkan metode pembelajaran yang tepat, merumuskannya dalam RPP, dan melibatkan siswa secara aktif dalam pembelajaran.

Model yang digunakan adalah model penelitian deskriptif kualitatif. Penelitian deskriptif kualitatif bertujuan untuk menggambarkan dan atau mendeskripsikan karakteristik dari fenomena. Penelitian deskriptif paparannya bersifat naratif (banyak uraian kata-kata). Apabila semua aspek dari fenomena sudah berhasil dijelajahi, maka peneliti ingin menggambarkan karakteristik dari fenomena secara utuh dan menyeluruh dengan uraian kata-kata dan kalimat yang naratif.

Pengumpulan data merupakan suatu proses pengadaan data untuk keperluan penelitian. Adapun teknik pengumpulan data yang digunakan dalam penelitian ini adalah metode observasi, wawancara dan dokumentasi.

Menurut Margono (2000: 190) pengolahan data atau analisis data dibagi menjadi dua yaitu non statistik dan analisis statistik. Untuk mempermudah peneliti dalam melakukan analisis data, peneliti menempuh langkah-langkah sebagai berikut:

a. Menyeleksi Data

Menyeleksi data yaitu data yang telah diperoleh dapat diseleksi manakala data yang diperlukan serta dapat mendukung analisa data yang dipergunakan.

b. Klasifikasi Data

Klasifikasi data yaitu mengelompokkan data-data yang telah diseleksi sesuai dengan kebutuhan dan permasalahan yang akan diteliti.

c. Penarikan Kesimpulan

Penarikan kesimpulan yaitu membuat kesimpulan dari data-data yang telah diperoleh selama penelitian. Data-data tersebut diperoleh dari metode wawancara dan metode dokumentasi.

\section{Hasil dan Pembahasan}

\section{a. Metode yang dominan digunakan oleh guru dalam pembelajaran}

Pemilihan metode pembelajaran merupakan salah satu upaya mengimplementasikan strategi agar terwujudnya tujuan pembelajaran yang telah dirumuskan. Perumusan tujuan pembelajaran harus dibarengi dengan pemilihan metode pembelajaran yang tepat. Dengan demikian rumusan tujuan pembelajaran harus mengarah pada ketiga ranah kompetensi yaitu baik ranah kognitif, apektif dan psikomotor.

Berdasarkan data yang ditemukan, diketahui bahwa dari delapan guru IPS yang dijadikan sebagai sampel penelitian di delapan sokolah dasar ditemukan bahwa metode pembelajaran yang dirumuskan dalam RPP pada setiap kali pertemuan dituliskan lebih dari satu metode pembelajaran. 
“62.5\% guru IPS merumuskan metode pembelajaran dalam RPP-nya adalah metode ceramah, diskusi, pemberian tugas dan resitasi, kerja kelompok, tanya jawab, demonstrasi dan eksperimen, sosiodrama, tutor sebaya dan pengajaran individual" (Doc/RPP/G-IPS).

Setelah dilakukan analisis skenario pembelajaran khususnya pada kegiatan inti pembelajaran dapat disimpulkan bahwa $62.5 \%$ guru IPS tidak konsisten menggunakan metode pembelajaran sebagaimana yang telah dirumuskan. Hal ini menunjukkan bahwa keterampilan sosial siswa yang diharapkan muncul sangat sulit dicapai karena metode yang digunakan sangat tidak sesuai tujuan pembelajaran.

Berdasarkan data yang diperoleh di lapangan menunjukkan bahwa terdapat $62.5 \%$ ditemukan guru IPS dalam melaksanakan pembelajaran lebih dominan menggunakan metode ceramah dan tanya jawab serta $37.5 \%$ yang lainnya metode pembelajaran yang digunakan sudah mengarah pada penerapan metode pembelajaran kooperatif

\section{b. Rumusan tujuan yang mengarah pada pencapaian keterampilan sosial pada RPP}

Tujuan pembelajaran merupakan acuan bagi guru untuk memilih dan menetapkan metode pembelajaran yang sesuai sehingga efektif dalam pencapaiannya. Berdasarkan analisis RPP menunjukkan bahwa tujuan pembelajaran yang dibuat oleh guru pada pembelajaran IPS sesungguhnya sudah mengarah pada pencapaian ranah psikomotor termasuk keterampilan sosial siswa. Disamping tujuan kognitif, dalam RPP yang telah dibuat oleh guru juga tercantum rumusan tujuan pendidikan karakter yang diharapkan dapat muncul selama proses pembelajaran.

"62.5\% guru merumuskan perilaku yang diharapkan muncul selama proses pembelajaran berupa kerjasama, rasa percaya diri, peduli sesama, tanggung jawab, tekun, teliti, kerja keras, toleransi, demokrasi, rasa ingin tahu, kreatif, disiplin, sopan santun dan berbudi pekerti luhur. 37.5\% guru tidak merumuskan secara tertulis di dalam RPPnya tentang kompetensi sebagaimana tersebut di atas" (Doc/RPP/G-IPS).

Setelah dilakukan analisis terkait dengan perilaku-perilaku positif yang diharapkan muncul dalam proses pembelajaran berupa kompetensi keterampilan sosial siswa ditemukan bahwa dari kelima guru IPS ternyata tidak satupun dalam RPP yang mencantumkan instrumen untuk merekam pencapaian kompetensi tersebut. Disamping itu, metode pembelajaran yang digunakan masih sangat dominan metode ceramah sehingga sangat tidak mungkin untuk mewujudkan tercapainya kompetensi lain selain kompetensi ranah kognitif. 


\section{c. Kesesuaian antara metode yang dirumuskan dalam RPP dengan kegiatan inti pembelajaran}

Kegiatan inti pembelajaran sangat berkaitan dengan sintak dari metode pembelajaran yang digunakan. Kegiatan inti pembelajaran merupakan cerminan pengalaman belajar yang harus dialami oleh siswa dalam belajar. Dengan demikian, kegiatan inti pembelajaran harus disesuaikan dengan langkah-langkah penerapan dari metode pembelajaran yang digunakan.

Berdasarkan analisis data ditemukan bahwa $62.5 \%$ dari guru IPS tidak memilih salah satu metode yang relevan dengan tujuan pembelajaran, artinya guru hanya menuliskan berbagai metode pembelajaran yang digunakan. Setelah dianalisis relevansi kegiatan inti dengan metode yang dicantumkan dalam RPP ternyata tidak sesuai dengan langkah-langkah pembelajaran yang dibuat dalam skenario pembelajaran. Dari delapan sekolah yang diambil sebagai lokasi penelitian, menunjukkan bahwa lima guru IPS sekolah dasar di kecamatan Sumbawa ditemukan bahwa guru tersebut lebih dominan merumuskan skenario pembelajaran yang mengarah pada langkah-langkah metode ceramah. Sedangkan tiga guru IPS lainnya merumuskan sekenario pembelajaran sesuai dengan metode yang dicantumkan dan lebih mengarah pada model pembelajaran kooperatif.

Dengan demikian dari delapan guru IPS sekolah dasar di kecamatan Sumbawa dapat disimpulkan bahwa $3.75 \%$ diantaranya dapat dikatakan mampu mengembangkan keterampilan sosial siswa sedangkan $62.5 \%$ guru IPS lainnya belum mampu mengembangkan keterampilan sosial siswa jika dilihat dari rumusan skenario pembelajaran yang telah direncanakan.

\section{d. Keterlibatan siswa dalam Proses pembelajaran}

Berdasarkan hasil observasi dapat ditarik kesimpulan bahwa guru IPS dalam merencanakan pembelajaran sebagian besar sudah merumuskan kompetensi keterampilan sosial. Sebagian besar guru IPS mencantumkan berbagai metode pembelajaran dalam RPP akan tetapi relevansi dengan sekenario pembelajaran sangat rendah karena pada kegiatan inti pembelajaran ditemukan $62.5 \%$ guru merencanakan pembelajaran lebih mengarah pada metode ceramah dan tanyak jawab. Proses pelibatan siswa secara utuh dalam pembelajaran masih sangat rendah sehingga dapat disimpulkan bahwa 62.5\% guru IPS dari delapan Sekolah Dasar di kecamatan Sumbawa yang dijadikan sebagai lokasi penelitian masih belum dapat mengembangkan keterampilan sosial siswa melalui proses pembelajaran. 


\section{e. Pembahasan.}

Tujuan pembelajaran merupakan acuan bagi guru untuk memilih dan menetapkan metode pembelajaran yang sesuai sehingga efektif dalam pencapaiannya.Tujuan pembelajaran merupakan titik tolak berfikir guru dalam menyusun sebuah Rencana Pembelajaran, yang mewarnai komponen-komponen perencanan lainnya (Akhmad Sudrajat, 2009). Merumuskan tujuan pembelajaran bukanlah perkara yang mudah dan dapat dilakukan secara sembarangan, melainkan harus memenuhi beberapa kriteria tertentu. Oemar Hamalik (2005) menyatakan bahwa komponen-komponen yang harus terkandung dalam tujuan pembelajaran, yaitu (1) perilaku terminal, (2) kondisi-kondisi dan (3) standar ukuran. Mager (Hamzah B. Uno, 2008) menyatakan bahwa tujuan pembelajaran sebaiknya mencakup tiga komponen utama, yaitu: (1) menyatakan apa yang seharusnya dapat dikerjakan siswa selama belajar dan kemampuan apa yang harus dikuasainya pada akhir pelajaran; (2) perlu dinyatakan kondisi dan hambatan yang ada pada saat mendemonstrasikan perilaku tersebut; dan (3) perlu ada petunjuk yang jelas tentang standar penampilan minimum yang dapat diterima. Dengan demikian maka proses perumusan pembelajaran untuk meningkatkan keterampilan social siswa tidaklah merupakan suatu pekerjaan yang dianggap sebagai kegiatan yang asal-asalan karena rumusan tujuan tersebut merupakan acuan bagi guru dalam memilih dan menetapkan metode pembelajaran. Dengan demikian maka tujuan pembelajaran harus didasarkan pada apa yang semestinya dikuasai dan dimiliki oleh siswa untuk hidup dalam masyarakat. Disamping itu, peran metode pembelajaran juga sangat menentukan. Tidaklah mungkin keterampilan sosial siswa dapat diwujudkan melalui metode ceramah sebagai metode yang dominan digunakan oleh guru dalam pembelajaran di kelas. Semestinya guru dapat melakukan perbaikan pembelajaran sebagai upaya mengembangkan keterampilan social siswa dengan menggunakan pendekatan konstruktivistik. Dalam pendekatan konstruktivistik proses belajar-mengajar dilakukan bersama-sama oleh guru dan peserta didik dengan produk kegiatan adalah membangun persepsi dan cara pandang siswa mengenai materi yang dipelajari, mengembangkan masalah baru, dan membangun konsep-konsep baru dengan menggunakan evaluasi yang dilakukan pada saat KBM (Kegiatan Belajar Mengajar) berlangsung (on-going evaluation). Dengan pengajaran ini, kualitas pengajaran dapat ditingkatkan, siswa dipandang sebagai individu yang mandiri yang memiliki potensi belajar dan pengembang ilmu. Apabila pendekatan itu digunakan maka guru IPS 
dapat memandang siswa sebagai rekan belajar dan pengembang ilmu sehingga akan tercipta hubungan yang kemitraan antara keduanya (Nana Supriatna, http://file.upi.edu).

\section{Kesimpulan}

Berdasarkan deskripsi dan analisis data penelitian dapat disimpulkan bahwa $62.5 \%$ guru IPS Sekolah Dasar di kecamatan Sumbawa belum mampu secara maksimal dalam mengembangkan kompetensi keterampilan social siswa baik dilihat dari metode yang dominan digunakan, relevansi metode dengan sekenario pada kegiatan inti pembelajaran, maupun hasil observasi selama proses pembelajaran berlangsung. Akan tetapi berdasarkan rumusan tujuan pembelajaran $62.5 \%$ guru sudah merumuskan kompetensi pada ranah kognitif, apekti, dan psikomotor termasuk keterampilan sosial siswa di dalamnya.

\section{Referensi}

Akhmad Sudrajat. 2009. Apa dan Bagaimana Tujuan Pembelajaran Itu. Diakses pada ttps://akhmadsudrajat.wordpress.com/2009/08/30/tujuan-pembelajaran-sebagaikomponen-penting-dalam-pembelajaran, tangga 27-12-2014.

Barth, J. L. 1990. Methods of Instruction in Social Studies Education. Lanham: University Press of Amerika.

Enok Maryani \& Helius Syamsudin: Jurnal Penelitian Vol. 9 No. 1 April 2009.

Hamzah B. Uno. 2008. Perencanaan Pembelajaran. Jakarta: PT Bumi Aksara

Margono. 2009. Metodologi Penelitian Pendidikan. Jakarta: Rineka Cipta.

Nana Supriatna. Pendekatan konstruktivistik pembelajaran IPS SD dalam membangun keterampilan social. Diakses pada http://file.upi.edu/Direktori/dualmodes/pendidikan_ips_di_sd/bbm_2.pdf, tanggal 27-12-2014.

Nursid Sumaatmadja. 2006. Konsep Dasar IPS. Jakarta: Penerbit Universitas Terbuka.

Omar Hamalik.2005. Perencanaan Pengajaran Berdasarkan Pendekatan Sistem. Bandung: Bumi Aksara.

Savage, T. V. '\&' Amstrong, D. G. 1996. Effective Teaching in Elementary Social Studies. New Jersey: Pretince-Hall, Inc. A Simon \& Schuster Company Englewood Cliffs.

Somantri, Muhammad Numan. 2001. Menggagas Pembaharuan Pendidikan IPS, bandung: Remaja Rosdakarya.

Suwarma Al Muchtar. 2005. Strategi Pembelajaran IPS, Pascasarjana UPI.

Windmiller, M. 1976. Moral development. Dlm. Adams. J.F. (pnyt.). Understanding adolescence: current developments in adolescent psychology: 176-198. Boston: Allyn and Bacon, Inc. 